\title{
LEGAL PROTECTION FOR APARTMENT BUYERS DUE TO ACTION OF THE DEFAULT DEVELOPER
}

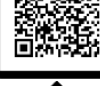

\section{DR. SUWARDI, S.H., MH}

Narotama University, Law Faculty, maswad0634@gmail.com

\section{Article history:}

Accepted 18 June 2019

Available online 24 July 2019

\section{Keywords:}

Buyers

Apartments

Legal protection

\begin{abstract}
A b s t r a c t
Act No. 20 of 2011 on the towers to make the legal basis for vertical residential building whose ownership is shared objects, piece together and ground together. With Improved and national economic growth are positive also helped encourage and spur improve the provision of residential development condotel in several major cities in Indoenesia this happens because of the looseness of the Government's policy on the provision of building vertical form of the apartment plus more because of market demand and the people who continue to increase, especially for the middle to high society and it is believed Developer these conditions will continue to increase and grow as global developments that occurred in the decade as it is today. Thus the government, especially the Ministry of Housing (Kemenpera) must anticipate on these developments to immediately find a solution. Fulfillment of the housing needs in the form of building vertical shape of one of them can be done through the construction of residential apartments. Apartment development policy to be one attractive option to do both by government and private sector employers as the property as part of an urban housing development in the region, especially given the increasingly expensive and limited availability of land.
\end{abstract}

\section{Introduction}

The development of housing demand, or shelter in Indonesia every year increasing it brings beneficial impact on the apartment as the developer in its business as a provider of business occupancy of apartment dwellings commercial interchanges. The main objective in the procurement Developer apartment occupancy is indeed profit oriented solely profit. Act No. 20 of 2011 on flats to make the legal basis for vertical residential building whose ownership is shared objects, shared parts and shared land.

Apartment development policy to be one attractive option to do both by government and private sector employers as the property as part of a housing development, especially in urban areas increasingly expensive considering the limited availability of land. Construction of the apartments is one alternative solving housing needs and settlement, especially in urban areas whose population continues to increase with various activities and all efforts so that the needs of occupancy is required for construction of apartments to reduce the use of land, creating open spaces of the city is more spacious and can be used as a way to rejuvenate the city for slum areas.

Physically apartment is a form of multi-storey dwelling in buildings where there are structural parts can be used individually and separately equipped with parts / objects that are used together (Hutagalung, 2002). According to Arie. S Hutagalung another purpose of construction of flats is (Ibid, 2002):

To meet the needs of a decent and healthy housing;

Realizing settlements which are harmonious, and balanced;

Rejuvenate slum areas;

Optimizing urban resources;

Encourage high density residential. 
Their occupancy of the apartment, which is one of renewal for the residents of a metropolitan city with the problem of population increases rapidly as the number of residential apartments which follows the demands of the market as in other countries in densely populated Indonesian population, especially in big cities will eventually become a necessity are urged to accept the presence of the apartment occupancy become a necessity that can not be bargained again because of dense activity that is run for the job need a place to stay that is more efficient both in terms of time, effort and close to the business environment (Hutagalung, 2005).

Apartment ownership status (strata title) s, effectively, the term strata title is not in the dictionary Indonesian legal literature. The term strata title is used in countries such as Singapore and Australia, which in essence allows the joint ownership horizontally and vertically. Because target market in Indonesia also for business people from abroad, then the naming of strata title given to be ttarget market understand more about the legal status of the object being marketed. In Indonesia, basically strata title is the ownership of the apartment units (hasarusun). Strata title is also the right of joint ownership of a building complex consisting of the exclusive right to personal space and collective rights over public space. That is, in a private room (apartments), the owners are not bound to the rules. While the public space, owner bound rules for public spaces common property of all residents. The concept of strata title is regulated in Act 16 of 1985 replaced Law No. 20 Year 2011 on the Flats, which regulates procedures for development, ownership, and management of the occupants of the apartment.

Rights Over Apartment Building:

a. Individual ownership rights over apartment units used separately,

b. Joint rights to parts of condotel buildings,

c. Collective rights over objects,

d. Joint rights to land

One problem is the protection of apartment unit buyer is so weak it is because the developers tend not provide detailed information about consumer rights concerns (Hutagalung, 2005). In this issue should be taken a clear who is responsible for the protection of consumers who tied an agreement on sale and purchase transactions. This has resulted in the Developer who have less good intentions and no responsibility will take advantage of such benefits. Unit residential apartment units will be marketed by the developer by way of sale by reservation. Sale and purchase of the unit of the apartment, mail order is one of the initial document that would be acceptable consumers who already intend to buy units of the apartment units.

\section{Problem Formulation}

Based on the above research background, the authors formulate the problem as follows:

1. What forms Developer defaults in the purchase agreement apartment unit and a contributing factor?

2. What efforts do apartment unit buyers to claim damages as a result of default Developer?

\section{Objectives}

Objectives to be achieved in this study are:

1. To find out what are the forms of default developer in the purchase agreement apartment unit and a contributing factor.

2. To find out what efforts can be made by the buyer for the apartment unit demanding damages as a result of default.

\section{Benefits of Research}

The benefits expected to be obtained from the results of this study are:

\section{Theoretical}

For the writer to develop the science of law:

a. To increase knowledge and insight into the writer as well as to benefit the readers, especially in matters of contract law / contract law and consumer protection law apartment.

b. Contribute and thought to contribute to the development of jurisprudence, especially the contribution of academic research in the field of contract law / contract law and consumer protection laws compartment.

\section{Practical}

a. The results of this study will be useful as a source of literature in the form of contributions to the development of legal science, especially for those interested in researching more about the legal agreement / contract, the law of flats and consumer protection laws.

b. The results of this study to provide input and feedback to the competent authorities in the development of the law of treaties / contracts, legal flats and consumer protection laws.

c. Can provide input to parties concerned with the implementation of sale and purchase of units of flats.

\section{Literature Review}

\subsection{Understanding Apartment In General.}

Apartment meaning is home in the form of flats. So, the difference is the emphasis, one on the right, while the other on the 
physical building. Is a model of residence only take a small portion of a building or a space as well as a place to stay with a model apartment? The apartment rooms or more (rooms) that are designated as a shelter, there are in a building that usually has a room or another room like that (Poer wadarminta, 1991). A residential complex and not homes that stand alone (Joseph de chiara, Time Saver Standards for Building Types). A room or several sets of types have similarities in a building used as a dwelling house (Stein, 1967). The term comes from the apartment of the United States, namely apartments, while the term flat coming from the United Kingdom. Apartment and flats refer to residential units that occupy a specific part of a building. Apartments and flats refers to the physical building. We also often hear the term Stratas title which is a concept that refers to the separation of a person's rights against multiple tiers or levels.

Understanding Flats can be found in Article 1 of Law No. 20 of 2011 on the Flats. Although the terms used to describe the multistorey residential very diverse but the legislation we are just about the terms flats.

Thus a bunk house consists of:

1. The units, each of which can be owned and used separately (apartment units)

2. Shared section

3. Shared objects

4. Shared land

Even lately too many developers who build with the designation of the mixture (residential non-residential, as much in demand by the public and more practical, in which the floor 1 (one) to 5 (five) for non-residential or kiosks (commercial) while the floor will be used for residential or called apartments or hotels, and the selling price (commercial value) in a mixture of flats is determined by:

1. For non-residential sales price is more expensive when compared to occupancy.

2. The selling price is determined by where the floor.

a. For occupancy, the higher the floor layout, the more expensive (higher) selling price or commercial value.

b. For non-residential, the lower floor, the more expensive (higher) selling price or commercial value.

The occupants in an environment Flats are good for both residential and nonresidential shall establish a Tenant Association to organize and manage the common interest concerned as the ownership, occupancy and management.

\subsection{Land Acquisition}

When the location requested permission has been approved by the Local Government then made his next activity to acquire land / location concerned. Application for land rights and certificates The relevant rights to the application for land rights and certificates of management rights / Building rights are carried out by the developer (developer), if the development organizer (developer) has fulfilled the requirements to obtain the land concerned, then submits a request for issuance Building Use Certificate on behalf of the developer.

\subsection{Request Building Permit (IMB)}

Construction organizers (developers) have not been able to build a condotel before obtaining a building permit from the local government which are preceded by a detailed plan that determines and separates each unit condotel unit as well as its proportionate comparison value, along with floor plans and site plans cut ownership limits.

\subsection{Endorsement descriptions}

Descriptions show clear boundaries of each as well as the proportional value comparisons made by the organizers of the construction (developers) and then applied for approval to the local governments. If the descriptions of the separation was approved by the authorities then Pemba opment organizers can quickly implement development activities. From these descriptions will appear units legally separate units melaluui manufacturing process Deed of Separation.

\subsection{Livable Permit}

After completing the construction of the development organizer, it is mandatory to apply for a living permit if the results of the inspection carried out truly prove that the conduct of condotel development in terms of architecture, construction, installation and other equipment is in accordance with the requirements contained in the IMB (Building Permit).

\section{Framework}

Pursuant to Article 33 paragraph (1) of the Constitution of the Fourth Amendment stated that: "The economy is structured as a joint venture based on family principles." Joint venture shows that business run is emerge from a variety of good cooperation that effort arising from legal business or joint venture that is not incorporated. Kinship constitution shows willingness to solve problems that occur in the business with professionalism amicable way without prejudice. Development in the economic field led to the growth of various business fields. As is known that the treaty law in the Civil Code adheres to the principle of consensus, meaning that to give birth to an agreement is enough to agree only and that the agreement was born at the time or second reached consensus or agreed.

In the Agreement Law applies a principle called the principle of consensualism, which means that basically agreements and agreements that arise therefore have been born from the moment 
the agreement is reached. In other words, the agreement is valid if the parties have agreed on the main matters to be agreed upon, and no formality is needed. The principle of consensualism is based on Article 1320 of the Civil Code, which reads: For the validity of an agreement four conditions are required :

1. agreed they were binding him.

2. The ability to make such agreements.

3. a certain thing.

4. a lawful reason.

Understanding selling affirmed in Article 1457 of the Civil Code as follows: "Buying and selling is an agreement whereby one party to bind himself to give up the right of a material, and the other party pays the price that has been promised. "From the meaning of Article 1457 of the Civil Code in the above can be stated further that:

1. There are two sides would bind himself, who each have rights and obligations arising from the sale and purchase of the engagement;

2. One party has the right to get or receive payment and is obliged to submit a material, while the other party has the right to obtain or accept a material and is obliged to submit a payment;

3. The rights of one party an obligation to the other party, as well as its reverse, the requirement that one is the right of the other party;

4. If one of the unfulfilled rights or obligations are not met by one of the parties, there will be no engagement or selling.

Agreements sometimes detrimental to consumers, as they are made unilaterally businesses. Marketing businesses orally promises to attract consumers to buy, but in writing not to do. This will make it difficult for consumers in the proof.

If there is nothing to worry about the presence of this agreement is not because of the inclusion of the exoneration clause (exemtion clause) in the agreement. Exoneration clause is a clause which contains conditions limiting, or even removing entirely the responsibility that should be borne by the manufacturer or the seller Mariam Darus Badrulzaman define it as an agreement in which standardized terms exoneration and manifested in the form, with the following characteristics:

1. The contents are set unilaterally by the creditor stronger relative position of the debtor;

2. The debtor did not specify the content of the agreement;

3 . driven by needs, the debtor was forced to accept the agreement;

4. The written form;

5. prepared first in bulk or individually.

\section{Discussion}

\subsection{Development Apartment Construction in General}

Construction of the housing sector in Indonesia, in recent years greatly increased. For Southeast Asia (ASEAN), Indonesia is leading the list of countries with the highest growth in residential property. Listing fairly rapid growth caused the housing developer has the potential to do the competition in attracting buyers. The marketing strategy is experiencing a trend currently is marketing the project pre-selling system. This marketing Strategy becoming trend, especially for the developers who is to make sales before the product property stands, and even some developers who did the marketing strategy of pre project selling before the requirements are met, among others, Building Permit (IMB), construction permits and other permits.

\subsection{Conditions For Consumer Protection}

In-Law No. 8 of 1999 on Consumer Protection, as a developer in the category of businesses. Understanding the business communities in Article 1 paragraph 3 of the Consumer Protection stated "Businesses any person or business entity, either domiciled or conducting activities within the territory of the Republic of Indonesia, either individually or jointly by agreement for business activities in various economic fields".

For developers as entrepreneurs, in addition to any obligation as mentioned above, given the prohibition set out in Articles 8 to 17 of Law No. 8 of 1999 on Consumer Protection. Article 8 of Law No. 8 of 1999 on Consumer Protection, which set restrictions for businesses that are public and can be broadly divided into two (2), namely:

1. Prohibiton on the product itself, which is not eligible and appropriate standards to be used or occupied or used by consumers.

2. Prohibition on the availability of information that can not untrue, inaccurate, and misleading consumers.

In this process, the SP became integral part attachment of the SPA. PPJB contains provisions that will be used in the development process until home handover, such as home cost issues, method of payment, delivery time homes, until the requisite delivery of certificates. The provisions of the CSPA is what will prevail as the rule (law) for prospective buyers and developers, and will end at the time of the signing of the Sale and Purchase Agreements (AJB). In other words, the SPA as a bridge between the SP and AJB transaction process.

\subsection{AJB Letters Power}

Signing AJB made in front of Notary / PPAT who will take care of making the certificate home. Terms of the signing of the AJB is the repayment of housing prices by buyers and witnessed by the Notary / PPAT. If the repayment has been made through the 
bank before signing AJB is done, then the house payment receipts submitted to the Notary / PPAT and used as evidence for the certification process. If you've reached this stage, then the home buying process has been completed, the seller has received the payment of fees and the buyer has to get home along with a certificate proof of ownership. Only binding sale and purchase agreement is an agreement that was born due to the open nature of Book III Book of the Law

\subsection{Default actions and risks}

Default or breach of contract non-performance or achievements of the obligation duly agreed upon in the contract. This tort actions have consequences right from the onset of the injured party, requires parties who are in default to provide compensation or reimbursement. There are three kinds of default are: default does not meet achievement, default late for an achievement, and default not meet achievement. Responsibility can be in the definition of right as a legal responsibility of the person / entity to produce a product (producer, manufacturer), of the person / entity who is engaged in a process to produce a product (processor, assembler) or distribute (seller, distributors) of the product.

\subsection{Principles in Agreement}

1. The principle of liability based on fault, namely the principle that states that a new person can be held legally accountable if there is an element of error he committed.

This principle is quite common in criminal and civil law. In Article 1365 of the Civil Code which is commonly known as the article on acts against the law requires the fulfillment of four elements:

a. There is an actions

b. There is an error

c. There is a loss suffered

$\mathrm{d}$. There is a causal relationship between mistakes and losses; Altough definition of error is an element that is contrary to the law. The definition of law is not only contrary to the law but also propriety and decency in society.

2. The principle of the presumption to always be responsible (presumption of liability), which is the principle that states a defendant is always considered responsible until he can prove that he is innocent, so the burden of proof is on the defendant. The basic principle is a person is considered innocent until the reverse can prove it.

3. The principle of the presumption not always be responsible (the presumption of nonliability) That this principle is the opposite of the principle of the presumption to always be responsible, where the defendant has always been considered not liable to prove, that he is guilty.

4. The principle of absolute liability (Strict liability)

In this principle establishes that the error is not a determining factor, but there are exceptions that allow to exempt from responsibility. The principle of absolute liability in the general consumer protection laws in use right to snare the culprit that harm consumers. The principle of the responsibility is known as product liability.

5. The principle of responsibility with restrictions (limitation of liability) with this principle of responsibility, business actors may not unilaterally determine clauses that harm consumers, including limiting their maximum responsibilities. If there are restrictions, it must be based on applicable laws. Referring to the results of research in the field, it can be seen that the developer (developer) has made PPJB first in the form of a standard agreement. The characteristics of standard agreements, among others:

1. The contents are set unilaterally by the parties position (economy)

2. The debtor did not participate jointly determine the contents of the agreement

3. Encouraged by their needs, debtors were forced to accept the agreement

4. Form a certain (written)

5. Be prepared beforehand in bulk or individually.

To fill the SPA agreement, consumers in general approved the contents of the CSPA. Because consumers do not have much choice, because there are only two options for the consumer that is take it or leave it. In the first option the consequence is that consumers are ready to meet all of the terms and conditions set by developers and bear all risks associated with the ownership of the property. The second option then the consumer would mean failing to obtain the desired properties.

In substance, the SPA between developers (developers) to one another is different. However, in certain respects there are similarities, among others, relating to the subject matter of the agreement, method of payment, and delivery of the maintenance period, the building changes, penalties for late and forje majeur. Legal Protection for Consumers From the existence of a Pre Project Selling System by a Housing Developer,

\subsection{Settlement System In litigant}

Related to consumer dispute resolution in BPSK, then there are three (3) ways:

\section{a. Conciliation}


REMEDY this dispute can be taken on the initiative of either party or both parties, while the BPSK Assembly passive. BPSK Assembly served as intermediary between the disputing parties. Conciliation implies a unity of the party, which in the end the interests of moving closer and subsequently reached a settlement that is satisfactory to both parties (a measure of goodwill).

\section{b. Mediation}

This effort is taken on the initiative of either party or both parties. The difference with conciliation, the BPSK Assembly intermediary and being active as an advisor. Basically, mediation is a process whereby a third party, a neutral outsiders (aneutral outsider) to the dispute, invite the parties to the dispute to an agreed dispute resolution. In the end, an agreement will be achieved without adverse ways (nonviolent means), at least a good relationship (relationship) is created without conflict.

\section{c. Arbitration}

These efforts are accomplished by means of the parties fully devolved to the Assembly and decided BPSK to resolve consumer disputes that occur. Arbitration is a method of consumer dispute resolution in civil matters as may be approved by both sides, which can be binding and can be implemented / enforced. Compensation is implemented by way of renovating the developer back in the consumers home so that in accordance with the agreement previously agreed upon between the developer and the consumer.

\section{Conclusions and Recommendations}

The legal consequences of their pre-project system selling is that if businesses do not perform its obligations properly and consumers will make a complaint if the results are not accepted by agreement. This default actions have consequences right from the onset of the injured party. Legal protection for consumers from selling their preproject system is providing a means for consumers harmed can sue developers through the courts.

Selling the project pre system used by housing developers (developers) should prioritize the protection of purchasers (consumers). For example, by not applying standard agreement which led to the potential for conflict between the developer with the consumer becomes very large. BPSK existence should be a good way out in order to give legal protection by the government to consumer fraud carried out by the developers.

\section{References}

1. Soerjono Soekanto, Introduction to Legal Studies, Jakarta: The University of Indonesia (UI-Press), 2015

2. Marzuki, PM, Legal Research, 2010, Jakarta: Kencana

3. Erwin Kallo, Legal Guide for Owners / Occupants Housing (Condominium).

4. The apartments and Rusunami) Minerva Athene Pressindo, Jakarta: 2009

5. Rajagukguk Erman, et al, Consumer Protection Law, (Bandung: PT. Mandar Maju, 2000)

6. AZ Nasution, Consumer Protection Law An Introduction, (Jakarta: PT. Power Widya, 2000)

7. Ahmad Adi Winarto, Responsibility Developer For Consumer Protection Measures in the Housing Sector in Pati regency, Diponegoro University: Thesis, 2008.

8. Mirza Sulaiman, Position Consumer Housing Agreement, Reader Forward, Into Matter II.

9. Shidarta, Consumer Protection Law, Jakarta: Grasindo, 2000

10. Mariam Darus Badrulzaman, Arts, Business Law, Bandung: Alumni, 1994.

11. Munir Fuady, Contract Law, Bandung: Publisher PT. Citra Aditya Bakti, 1999.

12. Subekti, Trade Arbitration, Bandung: BPHN and Binacipta, 1992. 